\title{
Immobilization of mice following envenomation by cobras (Naja mossambica pallida)
}

\author{
CHARLES W. RADCLIFFE, THOMAS POOLE, FREDERIC FEILER, \\ NILS WARNOCH, THOMAS BYERS, ANDREA RADCLIFFE, and DAVID CHISZAR \\ University of Colorado, Boulder, Colorado
}

\begin{abstract}
Mice (Mus musculus, average weight $=20.8 \mathrm{~g}$ ), envenomated by red spitting cobras (Naja mossambica pallida), were immobilized significantly sooner if the cobra delivered multiple strikes (3) than if it delivered only a single strike. Many viperid snakes (e.g., rattlesnakes) strike only once per predatory episode, whereas elapids (e.g., cobras) typically strike two to three times. The present study indicates that the number of strikes delivered by cobras is correlated positively with the severity of envenomation and inversely with the probability of losing potential rodent prey. Poststrike behavior of red spitting cobras is discussed, and is compared with that of rattlesnakes.
\end{abstract}

Rattlesnakes typically strike and release adult rodent prey (Gans, 1966; Radcliffe, Chiszar, \& O’Connell, 1980), permitting the envenomated animals to wander freely while the venom takes effect. Also, most rattlesnake species that specialize on rodent prey usually strike only once during a predatory episode (O'Connell, Chiszar, \& Smith, 1982; Chiszar, Radcliffe, \& Byers, Note 1). These two traits (i.e., delivery of a single strike, and immediate release of the envenomated rodent) are characteristic features of rodent-directed predatory behavior in many viperid snakes, irrespective of whether the predators are ambushers (many rattlesnakes; Klauber, 1956; Chiszar et al., Note 1; Greene, Note 2) or relatively active hunters (mamushi, Agkistrodon blomhoffi; Chiszar et al., Note 1). Some elapid snakes (e.g., taipans, Oxyuranus scutellatus; Shine \& Covacevich, in press) also exhibit these and related traits (see also Radcliffe \& Chiszar, 1980, and O'Connell, Chiszar, Greenlee, \& Bacon, Note 3).

Cobras chase after rodents rather than wait in ambush, and they either hold mice in their jaws upon capture or they deliver multiple predatory strikes (Kardong, 1982; Chiszar et al., Note 1).

Kardong (1982) showed that the major determinant of whether or not Egyptian cobras (Naja haje) released mice was the retaliatory behavior of the latter. These cobras usually held mice after striking, but if the mouse was able to bite the cobra, then the mouse was released immediately. Our find-

The authors wish to thank John Behler and the New York Zoological Society for providing the specimens of Naja mossambica pallida. D. Chiszar is now at the National Science Foundation, Psychobiology Program, Washington, D.C. 20550. Reprint requests should be addressed to $C$. W. Radcliffe, Department of Psychology, University of Colorado, Campus Box 345, Boulder, Colorado 80309. ings agree completely with that report (Chiszar, Stimac, Poole, Miller, Radcliffe, \& Smith, in press; Chiszar et al., Note 1; Radcliffe, Stimac, Smith, \& Chiszar, in press; Radcliffe, Estep, \& Chiszar, Note 4): Red spitting cobras (Naja mossambica pallida) followed the released mouse and continued striking as long as the mouse was moving, but the cobras always released mice upon retaliation.

That cobras strike repeatedly may seem surprising in view of the well-known toxicity of their venom (Brown, 1973; Minton, 1974; Russell, 1980) and of the fact that they are frequently bitten by the mice during the delivery of multiple strikes. However, the fangs of all elapids are very short, compared with the fangs of viperids, and it is likely that elapid bites do not penetrate as deeply as do viperid bites. Perhaps repeated superficial bites are needed to accomplish the same degree of envenomation as a single deep (viperid) injection. Also, if elapid venom is injected over a period of time while the prey is held in the jaws, then the tendency to release retaliatory mice means that such mice would receive less venom and would require additional strikes to become immobilized. In either case, mice struck only once and then released should survive longer and travel farther from the site of attack than mice receiving multiple strikes. The present study was designed to obtain data on this issue.

\section{METHOD}

\section{Subjects}

Eleven red spitting cobras (Naja mossambica pallida) were venom donors. One hundred and twenty mice (Mus musculus, strain HS; 60 males and 60 females; mean weight was $20.8 \mathrm{~g}$, $\mathrm{SD}=.8$, for both sexes) were subjects. Twenty mice of each sex were nonenvenomated controls, 20 mice of each sex were struck once by a cobra, and 20 mice of each sex were struck three times by a cobra. Each cobra was used equally often to 
envenomate male and female mice and to strike once and three times. All envenomations occurred when cobras had been deprived of food for 1 week (i.e., on a regularly scheduled feeding day).

\section{Procedure}

Control subjects were simply suspended (by a thread tied to one leg) into a cobra's cage and held out of striking range for $3 \mathrm{sec}$. Then the mouse was immediately placed into a wooden open field $(100 \times 100 \times 90 \mathrm{~cm})$. The floor of this apparatus was marked into $3616.5-\mathrm{cm}$ squares; the number of squares traversed by the mouse during each of 40 successive 15 -sec periods was recorded. Experimental mice were also suspended in a cobra's cage (as described above), but they were moved to within the snake's striking range after $3 \mathrm{sec}$. The cobras usually released mice of this size immediately after striking (Chiszar et al., in press; Radcliffe et al., in press). The single-strike mice were then transported to the open field, where we recorded: (1) latency to cessation of locomotion, (2) latency to the loss of the righting reaction, (3) latency to die (defined as cessation of respiratory contractions), and (4) number of squares traversed during all successive 15 -sec periods until immobilization. A threestrike mouse was suspended into the cobra's cage until the third strike had been delivered, after which the mouse was transported to the open field, where the measures just described were taken. Whenever a cobra held either a one- or a three-strike mouse, the cobra's neck skin was pinched with long forceps. This stimulation probably mimics rodent retaliatory behavior, and it invariably elicited immediate release of the prey.

Single-strike mice were always in the open field within $3 \mathrm{sec}$ of being released by the snake, and three-strike mice were in the open field within $12 \mathrm{sec}$ after their first strike (mean = $11.7 \mathrm{sec}$ ).

All mice used in this experiment were subjects retired from behavioral experiments conducted in other laboratories at this university. All mice were eventually ingested by snakes in this laboratory.

\section{RESULTS}

Figures 1 and 2 present the results of this study. Male and female mice did not differ significantly on any measure recorded in this study, so data were pooled across the sex dimension for graphical presentation. Figure 1 shows the cumulative percentage of envenomated mice ceasing locomotion, losing the righting reflex, and dying over successive 15-sec periods. Mean cumulative distance traveled by envenomated mice is also shown in Figure 1. Figure 2 shows mean latencies to cease locomotion, lose the righting reflex, and die, as well as mean distance traveled. All measures in Figure 1 indicate that threestrike mice were immobilized sooner than one-strike mice. Also, three-strike mice did not travel as far in the open field as one-strike mice. Recall that threestrike mice were not placed into the open field until $11.7 \mathrm{sec}$ after the first strike, whereas one-strike mice were placed in the open field within $3 \mathrm{sec}$. This difference can be taken into consideration by displacing the three-strike curves to the right by one unit along the abscissa of Figure 1. When this was done, the outcomes of inferential statistical tests remained unchanged (see caption of Figure 1).
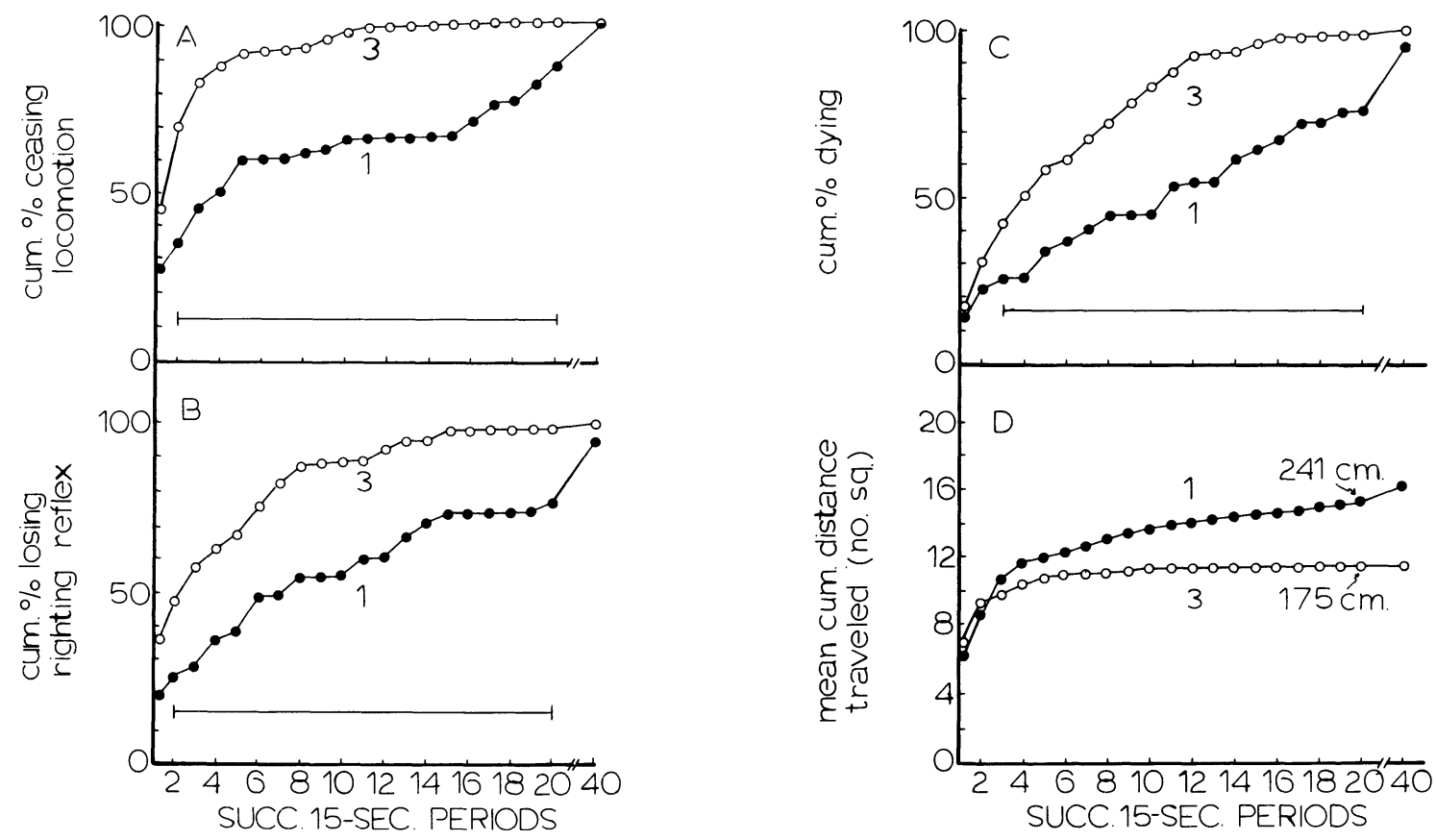

Figure 1. Cumulative percentage of one-strike and three-strike mice ceasing locomotion, losing righting reflex, and dying (Panels A, B, C, respectively). Data are plotted over successive 15-sec periods, and chi-squares were calculated to compare the groups on each measure during each 15-sec period. The horizontal lines in Panels A, B, and C indicate the periods during which significant differences existed between the groups. If the curves for three-strike mice are shifted to the right by one unit along the abscissa to compensate for the 11.7-sec delay in getting these mice into the open field, the pattern of significant differences does not change. Panel D presents mean cumulative distance (number of squares) traveled in the open field by one-strike and three-strike mice. The distance in centimeters is given for the 20 th 15 -sec period (see text for statistical analyses). 
Figure 2 confirms all of the impressions created by Figure 1, namely, that three strikes result in quicker cessation of locomotion $[F(1,76)=14.80$, $\mathrm{p}<.01]$, loss of righting $[\mathrm{F}(1,76)=13.02, \mathrm{p}<.01]$, and death $[F(1,76)=11.89, p<.01]$. Analysis of variance applied to distance traveled by controls, one-strike, and three-strike mice revealed a robust effect of groups $[F(2,114)=40.38, p<.01]$, and post hoc contrasts revealed a significant difference between one-strike and three-strike mice. All latency scores were reanalyzed after $11.7 \mathrm{sec}$ had been added to each measure taken on three-strike mice; all of these new tests indicated significant differences between one-strike and three-strike mice [cessation of locomotion, $\mathrm{F}=11.72$; loss of righting, $\mathrm{F}=11.51$; death, $\mathrm{F}=10.46$; all $\mathrm{dfs}=1,76$ and $\mathrm{ps}<.01$ ]. Likewise, the measure of distance traveled in the open field differed between one-strike and three-strike mice when appropriate adjustments were made to the scores of three-strike mice $[F(1,76)=2.96, .10>$ $\mathrm{p}>.05]$.

\section{DISCUSSION}

While rattlesnakes of many species strike only once during a predatory episode, red spitting cobras typically strike two or three times (Chiszar et al., Note 1). Presuming that contact with adult mice involves risk to the snakes (see Klauber, 1956, for

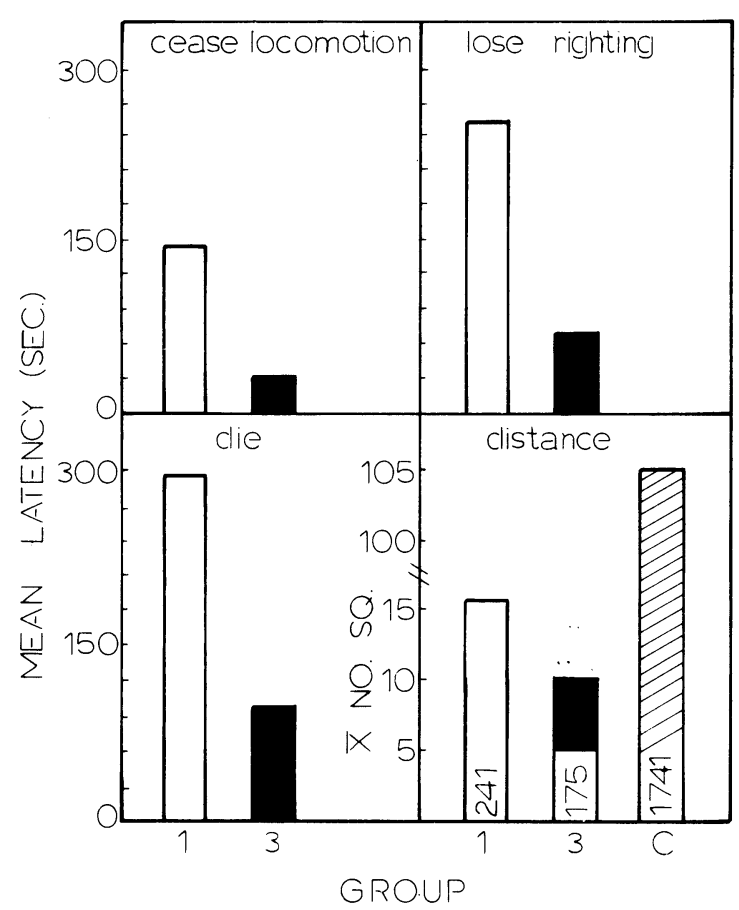

Figure 2. Mean number of seconds for one-strike and threestrike mice to cease locomotion, lose righting reflex, and die. Lower right panel gives mean number of squares crossed during a maximum of 5 min (or until cessation of locomotion) in the open field both for envenomated groups and for the control group. The numbers within the bars are distances in centimeters. a review), it is reasonable to hypothesize that cobras must be taking the extra risk for some reason. The present data indicate that multiple strikes in fact result in quicker immobilization of rodent prey than does a single strike. Yet it is also true that single strikes eventually killed the prey. On the average, onestrike mice got only $60-70 \mathrm{~cm}$ farther than the three-strike mice. Hence, it was definitely not the case that a single strike delivered a sublethal dose of venom. Accordingly, although we have shown that three strikes killed rodent prey more quickly than a single strike, it still seemed curious that cobras typically delivered multiple strikes when a single one would eventually do the job, with less risk of injury to the snake.

Rattlesnakes have an excellent ability to follow chemical trails left by envenomated prey (Dullemeijer, 1961; Golan, Radcliffe, Miller, O'Connell, \& Chiszar, 1982), but cobras may be less able to do this. We know that cobras can follow rodent trails (Radcliffe, Estep, \& Chiszar, Note 4), but they seem less attentive than rattlesnakes to these trails. Indeed, cobras seem to depend greatly upon visual cues arising from prey, especially from their movements. If an envenomated mouse were simply allowed to wander off and die $200-300 \mathrm{~cm}$ away from the site of attack, the eventual disappearance of movement cues might result in loss of prey (especially if the rodent managed to run into a burrow before the venom took effect). Hence, chasing and delivering multiple strikes may represent the cobra's attempt to maintain acceptable proximity to prey and to minimize or eliminate the need to follow chemical trails.

Venomous snakes feeding on adult rodent prey have probably been naturally selected to minimize two risks: (1) that of injury from rodent teeth and claws, and (2) that of losing the prey after the envenomating strike. Rattlesnakes have solved these two problems by striking once, releasing the prey, and then using their excellent trailing ability to bring them to the dead prey. Rattlesnakes typically do not move toward the prey until it has stopped moving, at which time the prey may be a considerable distance from the snake (Brock, 1980; Estep, Poole, Radcliffe, O'Connell, \& Chiszar, 1981; Brock, Note 5). Cobras, with their seemingly more acute vision and less well-developed trailing ability, have minimized the risk of losing the prey by keeping near (i.e., chasing) and delivering extra strikes while venom is taking effect. This reduces the need for chemosensory searching (Chiszar, Andren, Nilson, O'Connell, Mestas, Smith, \& Radcliffe, 1982; Chiszar, Radcliffe, \& Scudder, 1977) and for trailing after the mouse has died. The risk of injury seems to have been minimized by the development of sensitivity to poststrike, retaliating behavior of the prey (i.e., tactile feedback). The technique of releaseupon-retaliation coupled with chase-and-strike may be the best compromise to keep the mouse near and to reduce risk of injury.

\section{REFERENCE NOTES}

1. Chiszar, D., Radcliffe, C. W., \& Byers, T. Prey capture behavior in viperid and elapid snakes. Manuscript submitted for publication, 1983.

2. Greene, H. W. Empirical approaches to three problems in reptile ecology. Paper presented at the meeting of the Society for the Study of Amphibians and Reptiles and the Herpetologists' League, Raleigh, North Carolina, 1982.

3. O'Connell, B., Chiszar, D., Greenlee, R., \& Bacon, J. Strikeinduced chemosensory searching in elapid snakes at San Diego Zoo. Manuscript in preparation, 1983.

4. Radcliffe, C. W., Estep, K., \& Chiszar, D. Predatory behavior of the red spitting cobra (Naja mossambica pallida). Paper presented at the meeting of the Society for the Study of Amphibians and Reptiles and the Herpetologists' League, Raleigh, North Carolina, 1982.

5. Brock, O. G. Rattlesnakes in search of prey. Paper presented at the meeting of the Society for the Study of Amphibians and Reptiles and the Herpetologist's League, Knoxville, Tennessee, 1979. 


\section{REFERENCES}

Brock, O. G. Predatory behavior of Eastern diamondback rattlesnakes (Crotalus adamanteus): Field enclosure and $Y$ maze laboratory studies, emphasizing prey trailing behavior. Unpublished doctoral dissertation, Florida State University, 1980.

Brown, J. H. Toxicology and pharmacology of venoms from poisonous snakes. Springfield, Ill: Thomas, 1973.

Chiszar, D., Andren, C., Nilson, G., O'Connell, B., Mestas, J. S., Jr., Smith, H. M., \& Radcliffe, C. W. Strike-induced chemosensory searching in Old World vipers and New World pit vipers. Animal Learning \& Behavior, 1982, 10, 121-125.

Chiszar, D., Radcliffe, C. W., \& Scudder, K. M. Analysis of the behavioral sequence emitted by rattlesnakes during feeding episodes. I. Striking and chemosensory searching. Behavioral Biology, 1977, 21, 418-425.

Chiszar, D., Stimac, K., Poole, T., Miller, T., Radcliffe, C. W., \& Sмгтн, H. M. Strike-induced chemosensory searching in cobras (Naja naja kaouthia, N. mossambica pallida). Zeitschrift für Tierpsychologie, in press.

DullemeiJer, P. Some remarks on the funding behavior of rattlesnakes. Koninklijke Nederlandische Academie van Wetenschappen, 1961, Series C, 64, 383-396.

Este P, K., Poole, T., RAdCliffe, C. W., O'Connell, B., \& Chiszar, D. Distance traveled by mice (Mus musculus) after envenomation by prairie rattlesnakes (Crotalus viridis). Bulletin of the Psychonomic Society, 1981, 18, 108-110.

GaNs, C. The biting behavior of solenoglyph snakes-its bearing on the pattern of envenomation. Proceedings of the International Symposium on Venomous Animals. Sao Paulo, Brazil: Instituto Butantan, 1966.
Golan, L., Radcliffe, C. W., Miller, T., O'Connell, B., \& ChIszaR, D. Trailing behavior in prairie rattlesnakes (Crotalus viridis). Journal of Herpetology, 1982, 16, 287-293.

KARDong, K. V. Comparative study of changes in prey capture behavior of the cottonmouth (Agkistrodon piscivorus) and Egyptian cobra (Naja haje). Copeia, 1982, 337-343.

KLAUBER, L. M. Rattlesnakes (2 vols). Berkeley: University of California Press, 1956.

Minton, S. A. Venom diseases. Springfield, Ill: Thomas, 1974. O'Connell, B., Chiszar, D., \& SMith, H. M. Single vs. multiple predatory strikes by prairie rattlesnakes. (Crotalus viridis). Bulletin of the Maryland Herpetological Society, 1982, 18, 1-6.

RAdchiffe, C. W., \& Chiszar, D. A descriptive analysis of predatory behavior in the yellow lipped sea krait (Laticauda colubrina). Journal of Herpetology, 1980, 14, 422-424.

Radcliffe, C. W., Chiszar, D., \& O'Connell, B. Effects of prey size on poststrike behavior in rattlesnakes (Crotalus durissus, C. enyo, and C. viridis). Bulletin of the Psychonomic Society, 1980, 16, 449-450.

Radcliffe, C. W., Stimac, K., Smith, H. M., \& Chiszar, D. Effects of prey-size on post-strike behavior of juvenile red spitting cobras (Naja mossambica pallida). Transactions of the Kansas Academy of Science, in press.

Russell, F. R. Snake venom poisoning. Philadelphia: Lippincott, 1980.

Shine, R., \& Covacevich, J. Ecology of the highly venomous snakes: The Australian genus Oxyuranus (Elapidae). Journal of Herpetology, in press.

(Manuscript received for publication April 15, 1983) 